\title{
Changes in gel forming ability and protein solubility of pangasius (Pangasianodon hypophthalmus) muscle at different rigor stages during storage at room temperature $\left(28\right.$ to $\left.32^{\circ} \mathrm{C}\right)$ and in ice
}

\author{
MD. ISMAIL HOSSAIN, FATEMA HOQUE SHIKHA* AND SABINA YEASMIN \\ Department of Fisheries Technology, Bangladesh Agricultural University, Mymensingh 2202, Bangladesh \\ *Email: shikhafh@bau.edu.bd
}

\begin{abstract}
Gel forming ability of fish muscle is greatly influenced by the storage temperature and rigor stages. The present study was carried out to assess the changes in gel forming ability and protein solubility of pangasius (Pangasianodon hypophthalmus) muscle stored at room temperature $\left(28\right.$ to $\left.32^{\circ} \mathrm{C}\right)$ and in ice. Rigormortis in fish sample kept at room temperature (RT) and in ice started $1 \mathrm{hr}$ after death. The rigor-index reached a maximum $73.33 \%$ within $7 \mathrm{hrs}$ after death at RT and a maximum $87.09 \%$ within $4 \mathrm{hrs}$ in ice storage. At pre-rigor stage, the breaking force (BF) was $646.00( \pm 2.08 \mathrm{~g})$ which decreased to 266.67 $( \pm 3.53 \mathrm{~g})$ at post rigor stage at RT and from $660.33( \pm 1.45 \mathrm{~g})$ to $420.67( \pm 1.45 \mathrm{~g})$ in ice in one step stage. At $\mathrm{RT}$, grade of folding test (FT) decreased from "AA" to "A" and score of teeth cutting test (TCT) from 8 to 4. In ice also grade of FT and score of TCT decreased. Similarly, in two-step heating gels, BF decreased from $994.33( \pm 2.33 \mathrm{~g})$ to $403.00( \pm 1.15 \mathrm{~g})$ at post rigor stage at RT and $995.33( \pm 1.45 \mathrm{~g})$ to 552.67 $( \pm 3.71 \mathrm{~g})$ in ice. Immediately after catch myofibrillar protein solubility was $86 \%$ which declined below $30 \%$ after $24 \mathrm{~h}$ of storage at RT and below $30 \%$ after $28 \mathrm{~h}$ of storage in ice. The study concludes that the rigor period of pangasius may be extended up to $18 \mathrm{~h}$ by storing the fish in ice while at RT this period is only about $5 \mathrm{~h}$, which might contribute to slow down the gel degradation process.

Keywords: Gel forming ability, Pangasius muscle, Rigor stages, Icing
\end{abstract}

\section{Introduction}

There are a number of factors that influence the quality of fish, of which the most important one is the post-mortem changes that take place soon after death due to enzymatic action. A large number of different enzymes are naturally present in the flesh which are engaged in normal life processes such as tissue building and muscular contraction and relaxation. On death, however, they become involved in predominantly degradation reactions. One of these reactions is the gradual hydrolysis during the first few hours of glycogen to lactic acid, resulting when the process is complete in a fall in $\mathrm{pH}$ from about 7.0 to 6.8 depending on species and the condition of the fish. The decline in $\mathrm{pH}$ is accompanied by the natural post-mortem stiffening called rigor mortis.

Post mortem change is one of the most important aspects in maintaining the keeping quality of fish under various storage conditions. The state of rigor in association with other biochemical changes influences the meat quality of fish and higher animals (Penny 1967). There are three stages of rigor mortis: pre-rigor, in-rigor, post-rigor. Immediately after death the muscle of an animal become soft and limp, and can easily be flexed; at this time the flesh is said to be in prerigor condition. Eventually the muscles begin to stiffen and harder, and the animal is then said to be in-rigor; after some hour or day the muscle gradually being to soften and become limp again. The animal has now passed through rigor and muscle is in the post-rigor condition. The progress of rigor-mortis in association with ATP depletion and lactate accumulation is dependent 
on temperature and varies from species to species. It is generally accepted that low temperature delays the onset of rigor-mortis but several tropical fish species, such as tilapia, red sea bream and plaice are reported to have a shortened pre-rigor period when stored at $0^{\circ} \mathrm{C}$ (Iwamoto et al. 1985,1987, Iwamoto and Yamanaka 1986).

The qualitative characteristics of meat products are closely related to the functionality of muscle proteins. Myofibrillar proteins (MPs), comprising approximately $50 \%$ of total muscle proteins, are generally considered to be insoluble in solutions of low ionic strength $(<0.2 \mathrm{M})$, requiring high concentrations of salt $(>0.3 \mathrm{M})$ for solubilization. These soluble proteins are the ones which determine many functional properties of meat products, including emulsification and thermal gelation (Chen et al. 2015). The gel forming ability of the fish varies from species to species and within the species depending on the biological conditions of fish. The variation within the species is due to age, season, sex, death condition, freshness, fishing place, etc. (Shimizu et al. 1981, Kurokawa 1982, Shimizu and Kaguri 1986, Roussel and Cheftel 1988). There is still controversy on the influence of temperature on the onset and duration of rigormortis of fish. The objective of the present study was to follow the rigor-mortis of pangasius (Pangasianodon hypophthalmus) fish at room temperature $\left(28\right.$ to $\left.32^{\circ} \mathrm{C}\right)$ and in iced condition.

\section{Materials and Methods}

The experimental fish: Pangasius catfish, commonly called freshwater-pangasius $(P$. hypophthalmus), was used as raw material for the present study. The fish were collected live from K R market, Bangladesh Agricultural University campus, brought to the laboratory and kept both at room temperature $\left(28\right.$ to $\left.32^{\circ} \mathrm{C}\right)$ and in ice in an insulated box (fish: ice ratio 1:1). Ice was replaced at each 5-6 hours intervals in the insulated box (Plate I).

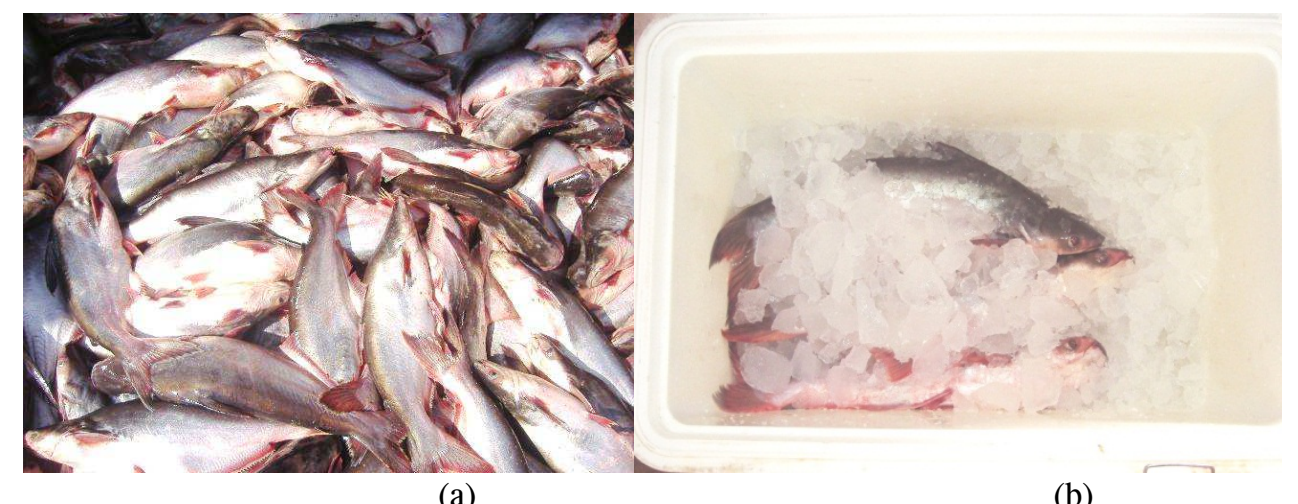

Plate I. Pangasius ( $P$. hypophthalmus) used for the study (a) Pangasius bought for the study,

(b) Pangasius stored in ice.

\section{Analytical Methods}

Rigor-index: "Rigor-index" was measured essentially according to Bito et al. (1983) and used as a parameter of rigor tension. Briefly, the fish was placed on a horizontal table with half of its 
body (tail part) kept out of the table (Plate-II). At selected time intervals, rigor-index was calculated by the following equation:

$$
\mathrm{D}_{0}-\mathrm{D}
$$

$$
\text { Rigor-index (\%) }=\begin{array}{ccc}
\text { Do } & \text { x } 100
\end{array}
$$

Where $\mathrm{D}_{o}$ and $\mathrm{D}$ represent the distances of the base of caudal fin from horizontal line of the table at the start of the experiment that is in pre-rigor and at subsequent storage periods respectively.

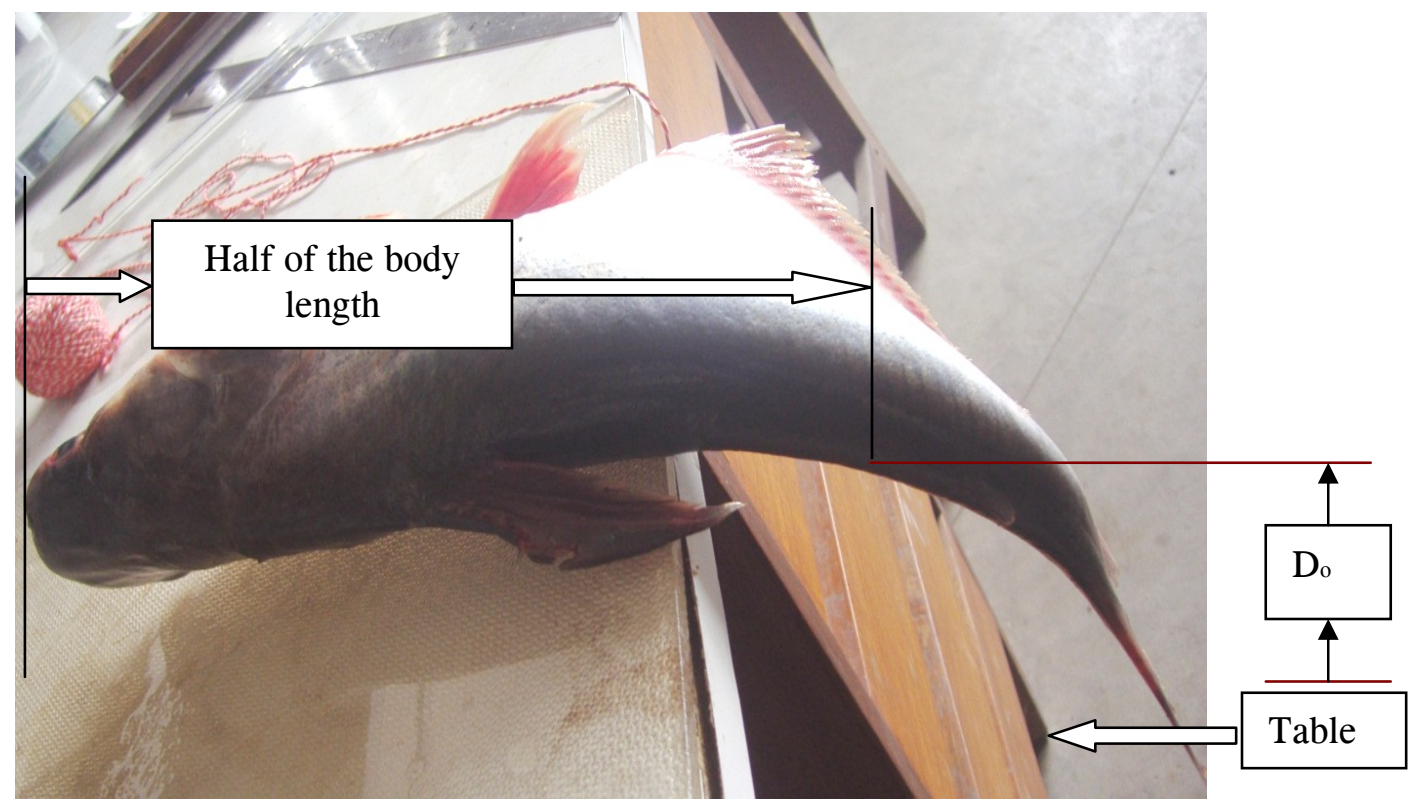

Plate II. Determination of rigor-index of pangasius ( $P$. hypophthalmus)

Estimation of changes in gel forming ability: The fishes were washed in chilled freshwater before they were beheaded and gutted. Dorsal and lateral muscles were excised as fillet form. Attention was paid to remove kidney tissues as they form globular masses which affect both texture and appearance of the product. The steps of preparation of meat paste included washing with water, beheading and gutting, filleting, deboning mincer, deboned mince, grinding with $3 \% \mathrm{NaCl}$ for $20 \mathrm{~min}$, and meat paste.

Preparation of gel: The paste in plastic casing cylinders(diameter $2 \mathrm{~cm}$, height $12 \mathrm{~cm}$ ) was heated to produce gel. Some samples were heated once only in well stirred water bath (One step heating), whilst the rest were heated twice (two step method) in triplicates. In one-step heating, samples were heated for $120 \mathrm{~min}$ in water at $40^{\circ} \mathrm{C}$. In two-step heating, the first heating was for $120 \mathrm{~min}$ in water at $40^{\circ} \mathrm{C}$, conveniently called pre-heating. After this preheating treatment, they were immediately heated for another $30 \mathrm{~min}$ in water at $85^{\circ} \mathrm{C}$. After heat treatments, the samples were taken out from the water bath, kept in iced water for $1 \mathrm{hr}$ and used for further tests. 
Measurement of gel-strength: The gel strength of the products was assessed by objective and organoleptic methods. A five person panel as described by Poon et al. (1981) was followed for the organoleptic assessments. The gel was removed from the cylinder and subjected to puncture test, folding test and teeth cutting test for physical measurements of the gel. Puncture test measured the breaking strength of the gel against insertion of a ball type plunger. The folding test measured the resistance against breaking along with the folds when sample discs of $1 \mathrm{~mm}$ thickness were folded into halves and then quarters and the teeth cutting test was a measure of the resistance of the disc cut by the incisors of members of the panel.

Puncture test: The gels were removed from the tube and cut into equal pieces of $2 \mathrm{~cm}$. The puncture test was done by measuring breaking force of the gel against the penetration of a ball type plunger. The cut gel was placed on the pan of an electric balance and a spherical plunger was penetrated onto it. The force in gram required to break the gel by the plunger was recorded from the balance.

Folding test: For folding test, a spherical disc of $1 \mathrm{~mm}$ thick gel was cut off and placed on the index and middle finger of the right hand, the disc was folded first into halves and then quarter by the help of the thumb and index finger. The gel was graded using the scores presented in Table I.

Table I. Grades used in the folding test of the gel

\begin{tabular}{cl}
\hline Grade & Results on folding \\
\hline AA & $\begin{array}{l}\text { No crack visible when disc is folded into quarter } \\
\text { No crack visible when disc is folded into half, but one or more cracks or } \\
\text { A }\end{array}$ \\
breaks are visible when folded into quarter. \\
B & One or more cracks or breaks are visible when folded into half. \\
C & Breaks, but does not split into halves. \\
D & Split into halves when folded into half. \\
0 & Sample too soft to evaluate. \\
\hline
\end{tabular}

Teeth cutting test: For teeth cutting test, disc gels of the same size used in folded test was supplied to the panelists to recognize the taste by cutting it through incisors and the gel strength was evaluated by numeral scores presented in Table II as suggested by Shimizu et al. (1981).

Table II. Score used in the teeth cutting test of the gel

\begin{tabular}{ll}
\hline Score & Characteristics of the gel \\
\hline $0-1$ & Paste or mud like gel \\
$2-3$ & Very frail gel \\
$4-5$ & Frail gel \\
6 & Medium gel strength \\
$7-8$ & Strong gel \\
$9-10$ & Very strong gel \\
\hline
\end{tabular}

Changes in the protein solubility: Myofibrils are a part of muscle protein. Myfibrillar protein solubility indicates the denaturation rate of protein. Myofibrils were prepared from ordinary muscles immediately after excision according to Perry and Grey (1956) with slight 
modifications. The muscle was chopped by a meat grinder and chilled minced muscle $(50 \mathrm{~g})$ was homogenized for $1 \mathrm{~min}$ in 5 volumes of $39 \mathrm{mM}$ borate buffer ( $\mathrm{pH} 7.1$ ) containing $25 \mathrm{Mm} \mathrm{KCl}$ and $0.1 \mathrm{mM}$ DTT. The homogenate was centrifuged for $15 \mathrm{~min}$ at $600 \times \mathrm{g}$. The residue obtained was again homogenized and centrifuged for $15 \mathrm{~min}$ at $600 \mathrm{xg}$. The light colored upper layer of the residue consisting mainly of myofibril was recovered with small volume of $39 \mathrm{mM}$ borate buffer ( $\mathrm{pH} 7.1$ ) containing $0.1 \mathrm{M} \mathrm{KCl}$ and $0.1 \mathrm{mM}$ DTT. The suspension was centrifuged for 15 $\min$ at $600 \mathrm{xg}$ to remove the supernatant. Myofibrils were diluted with 4 volume volumes of $39 \mathrm{mM}$ borate buffer $(\mathrm{pH} 7.1)$ containing $0.1 \mathrm{M} \mathrm{KCl}$ and $.1 \mathrm{mM}$ DTT and coarse materials removed by centrifugation at $400 \times \mathrm{g}$. The suspension was centrifuged for $15 \mathrm{~min}$ at $600 \times \mathrm{g}$ to sediment myofibril. After the pellet was washed three times in the same was, myofibril were suspended with a desired volume of $39 \mathrm{mM}$ borate buffer $(\mathrm{pH} 7.1)$ containing $0.1 \mathrm{M} \mathrm{KCl}$ to make a concentration of $10-15 \mathrm{mg} / \mathrm{ml}$.

Myofibrllar protein solubility: Two $\mathrm{ml}$ of myofibrillar suspensions $(5 \mathrm{mg} / \mathrm{ml})$ were homogenized with $2 \mathrm{ml}$ of $1 \mathrm{M} \mathrm{KCl}$ plus $100 \mathrm{mM}$ phosphate buffer $(\mathrm{pH} 7.0)$ using a homogenizer. The homogenate was allowed to stand at refrigerated temperature $\left(4^{0} \mathrm{c}\right)$ overnight. The suspension was centrifuged for $30 \mathrm{~min}$ at $900 \times \mathrm{g}$ in cold condition. The protein in supernatant was determined by Biuret method (Gornall et al. 1949).

\section{Results and Discussion}

Changes in rigor index: The progress of rigor mortis was more rapid in fish stored at room temperature (RT) $\left(28\right.$ to $\left.32^{\circ} \mathrm{C}\right)$ than in ice (Fig. 1). In fish stored at RT, rigor started $1 \mathrm{~h}$ after spiking and it reached to a maximum of $73.33 \%$, within $7 \mathrm{~h}$ after death. The rigor period lasted for about 5 hand then post rigor started. The muscle fully relaxed after $22 \mathrm{~h}$ of storage. Rigor also started within $1 \mathrm{~h}$ of death for fish stored in ice. Gradual progress in rigor was observed with the lapse of storage time. Rigor reached to a maximum of $87.09 \%$ within $4 \mathrm{~h}$; the rigor period continued for $22 \mathrm{hand}$ then muscle started to relax. The muscle relaxed up to $29 \mathrm{~h}$ of storage in ice without emitting any foul odor.

Time involved in each stages of the rigor development, duration and subsequent resolution of rigor-mortis depends on many factors such as species, size, and catching method, handling of the fish, temperature and the physical condition of the fish. Rigor-mortis is known to be dependent on temperature which influences the onset and the rate of progress of rigor. The results obtained in the present study are more or less similar to the findings of other researchers. Watabe et al. (1989) reported the progress of rigor up to $80 \%$ during storage at $10^{\circ} \mathrm{C}$ for mackerel and Hossain (1995) reported the progress of rigor up to $78 \%$ for mrigal (Cirrhinus mrigala) within $6 \mathrm{~h}$ after death at room temperature. In iced condition it reached to maximum value after about $10 \mathrm{~h}$ of death. 


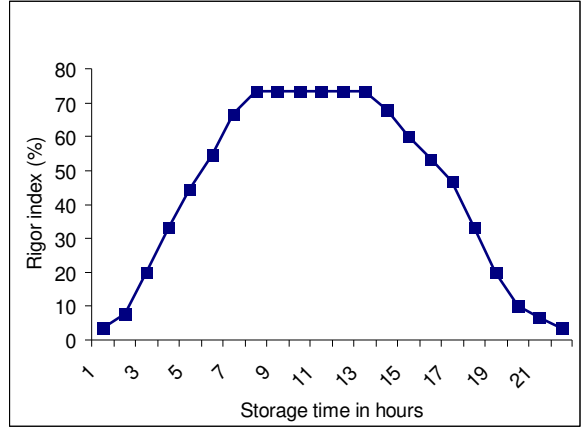

(a)

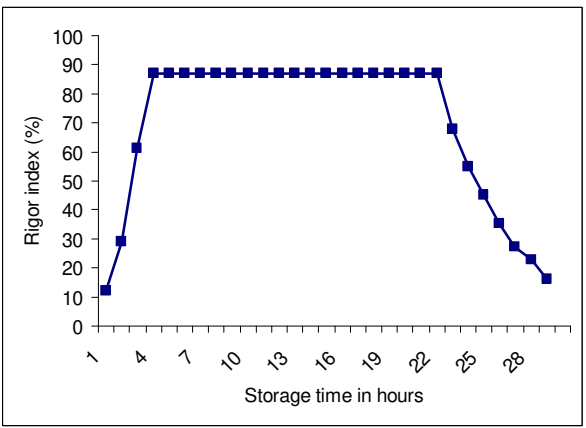

(b)

Fig. 1. Changes in rigor- index (\%) ofpangasius muscle; (a) room temperature (28 to $\left.32^{\circ} \mathrm{C}\right)$ and (b) ice

Changes in gel characteristics of one and two step heating gels: At the heating temperature of $20^{\circ} \mathrm{C}$ one step heating gels were too soft to measure the gel characteristics whereas for two step heating gels the breaking force (BF) was found 596.3 $\pm(3.28)$, folding test value "A" and teeth cutting test (TCT) 7. The highest BF was found $669.33 \pm(0.67)$ in one step heating gel at $40^{\circ} \mathrm{C}$. At this temperature folding test (FT) result showed grade "AA" indicating no crack visible when disc was folded into quarter and TCT also showed the highest score 9, indicating very strong gel. In case of two step heating gels highest $\mathrm{BF}$ was also obtained at $40^{\circ} \mathrm{C}$.but the value was quite high $(898.00 \pm 4.04)$ indicating the effect of further heating of the one step heating gels at high temperature for shorter period. Here, in two step heating gels also similar results for FT and TCT were observed at $40^{\circ} \mathrm{C}$ though the obtained results for these two parameters were comparatively higher than one step heating gels at $30^{\circ}$ and $80^{\circ} \mathrm{C}$ temperatures.

In the manufacture of heat-processed fish products produced from washed fish mince or surimi, two-step heating has been considered tohave tremendous gel enhancing effects (Ishioroshi et al. 1982, Niwa et al. 1991, Nowsad et al.1999,Park et al. 1996). Salt-ground fish mince paste added with ingredients if incubated at $30-50^{\circ} \mathrm{C}$ for $1-2 \mathrm{~h}$ before final cooking at $90-100^{\circ} \mathrm{C}$, the gel strength is increased by about 1.5 to 2 folds (Niwa et al. 1991). Reppond et al. (1995) noticed a 3-fold increment of gel strength in set and cooked products due to two-step heating treatment of Pacific herring. At low temperature around $30-50^{\circ} \mathrm{C}$ in fish, helical tail portion of myosin heavy chain unfolds and helps in intense cross-linking of proteins during high cooking temperature around $80-95^{\circ} \mathrm{C}$ (Ishioroshi et al.1982).

Table III. Changes in gel characters of one and two step heating gels prepared from pangasius muscle

\begin{tabular}{|c|c|c|c|c|c|c|c|c|}
\hline \multirow{2}{*}{$\begin{array}{l}\text { Type of } \\
\text { heating }\end{array}$} & \multirow{2}{*}{$\begin{array}{l}\text { Gel character- } \\
\text { istics measured }\end{array}$} & \multicolumn{7}{|c|}{ Heating temperature $\left({ }^{\circ} \mathrm{C}\right)$} \\
\hline & & 20 & 30 & 40 & 50 & 60 & 70 & 80 \\
\hline \multirow[t]{3}{*}{ One step } & $\mathrm{BF}$ & * & $\begin{array}{c}245.33 \pm \\
(1.45)\end{array}$ & $\begin{array}{c}669.33 \pm \\
(0.67)\end{array}$ & $\begin{array}{c}647.67 \pm \\
(1.45)\end{array}$ & $\begin{array}{c}600.67 \pm \\
(1.45)\end{array}$ & $\begin{array}{c}299.00 \pm \\
(1.00)\end{array}$ & $\begin{array}{c}209.67 \pm \\
(0.88)\end{array}$ \\
\hline & FT & * & A & AA & AA & AA & A & A \\
\hline & TCT & * & 6 & 9 & 8 & 7 & 6 & 5 \\
\hline \multirow[t]{3}{*}{ Two step } & $\overline{\mathrm{BF}}$ & $\begin{array}{c}596.3 \pm \\
(3.28)\end{array}$ & $\begin{array}{c}631.00 \pm \\
(1.00)\end{array}$ & $\begin{array}{c}898.00 \pm \\
(4.04)\end{array}$ & $\begin{array}{c}607.33 \pm \\
(4.26)\end{array}$ & $\begin{array}{c}541.67 \pm \\
(6.01)\end{array}$ & $\begin{array}{c}349.33 \pm \\
(2.96)\end{array}$ & $\begin{array}{c}303.67 \pm \\
(2.19)\end{array}$ \\
\hline & FT & A & AA & AA & AA & AA & A & A \\
\hline & TCT & 7 & 8 & 9 & 8 & 7 & 6 & 6 \\
\hline
\end{tabular}

* Gel too soft $\mathrm{BF}=$ Breaking force $($ Mean \pm SE); FT $=$ Folding Test; TCT $=$ Teeth Cutting Test 


\section{ISMAIL HOSSAIN et al.}

Changes in gel characteristics at different stages of rigor: Different stages of rigor has effect on the characteristics of gel. At pre-rigor stage BF was $646.00( \pm 2.08 \mathrm{~g})$ in one step heating gel which decreased to $266.67( \pm 3.53 \mathrm{~g})$ at post rigor stage at RT. The grade of FT and score of TCT also decreased from "AA" and 8 to "A" and 4 , respectively at the post rigor stage. Similarly, in ice, BF decreased from $660.33( \pm 1.45 \mathrm{~g})$ to $420.67( \pm 1.45 \mathrm{~g})$, grade of FT, "AA" to "A" and score of TCT, 6 to 4indicating that- at the later phase of rigor (at in rigor and post rigor stage) the gel strength decreases (Table IV).

Table IV. Changes in gel characteristics of one and two step heating gels prepared with pangasius ( $P$. hypophthalmus) muscle at different stages of rigor

\begin{tabular}{|c|c|c|c|c|c|}
\hline \multirow{2}{*}{$\begin{array}{l}\text { Types of } \\
\text { sample }\end{array}$} & \multirow{2}{*}{$\begin{array}{l}\text { Heating time } \\
\text { and } \\
\text { temperature }\end{array}$} & \multirow[t]{2}{*}{ Rigor stages } & \multirow[t]{2}{*}{ Measurement } & \multicolumn{2}{|c|}{ Obtained results } \\
\hline & & & & One-step heating gel & Two-step heating gel \\
\hline \multirow{9}{*}{$\begin{array}{c}\text { Room } \\
\text { temperature }\end{array}$} & \multirow{3}{*}{$\begin{array}{c}40^{\circ} \mathrm{C} ; 120 \\
\text { min (one step } \\
\text { heating) }\end{array}$} & \multirow[t]{3}{*}{ Pre-rigor } & $\mathrm{BF}$ & $646.00 \pm(2.08)$ & $994.33 \pm(2.33)$ \\
\hline & & & FT & AA & AA \\
\hline & & & TCT & 8 & 9 \\
\hline & \multirow{6}{*}{$\begin{array}{c}40^{\circ} \mathrm{C} ; 120 \\
\min \\
+ \\
80^{\circ} \mathrm{C} ; 20 \mathrm{~min} \\
\text { (two step } \\
\text { heating) }\end{array}$} & \multirow[t]{3}{*}{ In-rigor } & $\mathrm{BF}$ & $513.00 \pm(1.73)$ & $798.00 \pm(1.73)$ \\
\hline & & & FT & AA & AA \\
\hline & & & TCT & 6 & 8 \\
\hline & & \multirow[t]{3}{*}{ Post-rigor } & $\overline{B F}$ & $266.67 \pm(3.53)$ & $403.00 \pm(1.15)$ \\
\hline & & & FT & $\mathrm{A}$ & $\mathrm{A}$ \\
\hline & & & TCT & 4 & 4 \\
\hline \multirow{9}{*}{$\begin{array}{c}\text { Iced } \\
\text { condition }\end{array}$} & \multirow{3}{*}{$\begin{array}{c}40^{\circ} \mathrm{C} ; 120 \\
\text { min (one step } \\
\text { heating) }\end{array}$} & \multirow[t]{3}{*}{ Pre-rigor } & $\mathrm{BF}$ & $660.33 \pm(1.45)$ & $995.33 \pm(1.45)$ \\
\hline & & & FT & $\overline{\mathrm{AA}}$ & $\overline{\mathrm{AA}}$ \\
\hline & & & TCT & 6 & 9 \\
\hline & \multirow{6}{*}{$\begin{array}{c}40^{\circ} \mathrm{C} ; 120 \\
\text { min } \\
+ \\
80^{\circ} \mathrm{C} ; 20 \mathrm{~min} \\
\text { (two step } \\
\text { heating) }\end{array}$} & \multirow[t]{3}{*}{ In-rigor } & $\mathrm{BF}$ & $605.33 \pm(2.60)$ & $906.33 \pm(2.73)$ \\
\hline & & & FT & $\mathrm{AA}$ & $\mathrm{AA}$ \\
\hline & & & TCT & 6 & 9 \\
\hline & & \multirow[t]{3}{*}{ Post-rigor } & $\mathrm{BF}$ & $420.67 \pm(1.45)$ & $552.67 \pm(3.71)$ \\
\hline & & & FT & $\mathrm{A}$ & $\mathrm{A}$ \\
\hline & & & TCT & 4 & 4 \\
\hline
\end{tabular}

In case of two step heating gels, at pre rigor stage, BF was found $646.00( \pm 2.08 \mathrm{~g})$, which decreased to $266.67( \pm 3.53 \mathrm{~g})$ at post rigor stage while stored at RT. The grade of FT and score of TCT decreased from "AA" and 9 to "A" and 4, respectively. For the samples stored in ice, BF decreased from $660.33( \pm 1.45 \mathrm{~g})$ to $420.67( \pm 1.45 \mathrm{~g})$, grade of FT from "AA" to "A" and score of TCT value from 9 to 4 , indicating that the progress of rigor though affect the gel characterizes but storage of fish at low temperature contribute to increase the gel strength (Table IV). Hossain et al. (2019)applying both one and two step heating methods observed decrease of BF of gels prepared with Silver jewfish, Ribbon fish and Bombay duck during 10 days of ice storage. For the same fishes both in one and two step heating, the initial folding test (FT) grade decreased from 'AA' to ' $\mathrm{B}$ ' or ' $\mathrm{A}$ ' and teeth cutting test (TCT) scores decreased from 8 to below 3. The result obtained from the study clearly indicated that though two step heating contributed to increase the gel strength than one step heating but the gel strength decreased with the lapse of storage period in ice with is in accordance with the present study. Hossain et al. (2005) found a maximum breaking force from both washed and unwashed mince of queen fish (Chorinemus lysan) at the incubation temperature of $50^{\circ} \mathrm{C}$. The gel-strength of both unwashed and washed meat paste gradually declined with lapse of storage period which is quite similar to 
the findings of the present study. Varghese and Mathew (2017) observed that, the water holding capacity of the muscle Anabas testudineus decreased when the fish muscle entered in post rigor stage while cook loss and expressible water content were significantly increased. .The histochemical studies and textural profile analysis of fish muscle in their study proved that, the degradation of both collagen and myofibrillar protein induced the post-mortem tenderization and the resultant quality deterioration of iced stored Anabas testudineus fish. These results describe well the reason of decrease of breaking force and solubility of pangasius muscle with the progress of rigor in the present study during storage in ice.

Different stages of rigor have influence on the solubility of protein. Protein solubility of the samples stored at RT was found $86 \%$ at pre rigor stage of the fish. After that, solubility decreased continuously throughout in-rigor and post rigor stages (Fig. 2). While post rigor started, after $12 \mathrm{~h}$ of storage myofibrillar protein solubility decreased below $50 \%$. The solubility decreased further with the lapse of storage period and after $24 \mathrm{~h}$ of storage the solubility declined below $30 \%$. In the case of ice stored samples also the protein solubility was found $86 \%$ at the beginning of rigor. Afterward the myofibrillar protein solubility decreased continuously with the progress of storage period. The post rigor started after $22 \mathrm{~h}$ of ice storage and the protein solubility declined below $50 \%$ after $28 \mathrm{~h}$ of storage the solubility declined below $30 \%$. Protein solubility (\%) of three marine fish species (Silver jewfish, Ribbon fish and Bombay duck) were determined during ice storage by Hossain et al. (2019) which is quite similar to the results obtained in the present study. Seki et al. (1979) reported that the solubility of carp myofibrils decreased from $95 \%$ to $20 \%$ during ice storage of 2-3 weeks. Mehta et. al. (2014) observed, the solubility profile of proteins in high ionic strength buffer and calcium adenosine triphosphatase (ATPase) enzyme activity reduced significantly $(p<0.05)$ at the end of 22 days of ice storage. All these findings are more or less similar to the present finding.

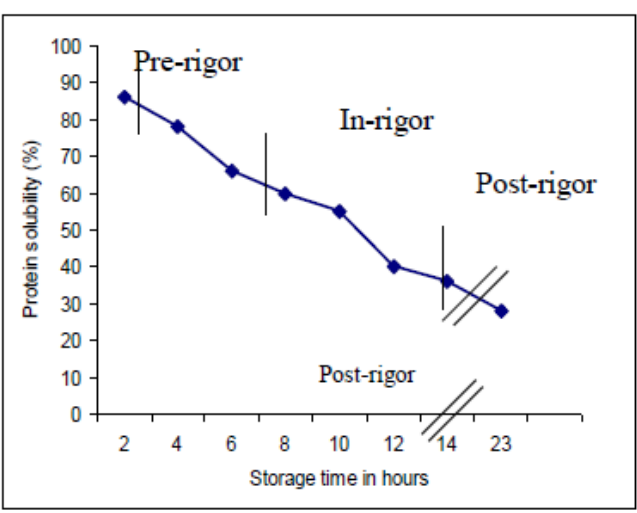

(a)

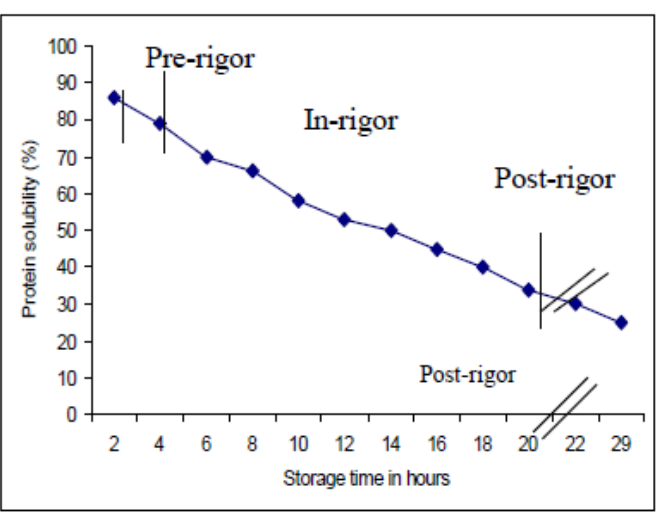

(b)

Fig. 2. Changes in protein solubility (\%) of pangasius (P. hypophthalmus) muscle at different stages of rigor; (a) at room temperature $\left(28\right.$ to $\left.32^{\circ} \mathrm{C}\right)$ and (b) in ice. 


\section{ISMAIL HOSSAIN et al.}

Rigor-mortis in fish sample kept at both room temperature and iced condition started $1 \mathrm{~h}$ after death. It was observed that rigor-index reached maximum $73.33 \%$ within $7 \mathrm{~h}$ after death at room temperature and $87.09 \%$ within $3 \mathrm{~h}$ after death in ice. The breaking force of the resulting gels was highest at $40^{\circ} \mathrm{C}$ at an incubation of $120 \mathrm{~min}$ at pre-rigor stage both at room temperature and in ice. Immediately after catch myofibrillar protein solubility was $86 \%$. The solubility decreased continuously with the progress of time and reached to $30 \%$ after $24 \mathrm{~h}$ of storage at room temperature and $28 \mathrm{~h}$ in ice. From the obtained results this study it can be concluded that ice storage of muscle extend the in rigor stage of pangasius muscle from $5 \mathrm{~h}$ to $18 \mathrm{~h}$ which might contribute to slow down the degradation process of protein.

\section{Literature Cited}

Bito, M., K. Yamada, Y. Mikumo and K. Amono, 1983. Studies on rigor-mortis of fish-1. Differences in the mode of rigor-mortis among some varieties of fish by modified cuttings method. Bull. Tokai Reg. Fish. Res. Lab., 109: 89-96.

Chen, X., K. Ron, Tume, X. Xu and G. Zhou, 2015. Solubilization of myofibrillar proteins in water or low ionic strength media: Classical techniques, basic principles, and novel functionalities. 3260-3280. https://doi.org/10.1080/10408398.2015.1110111

Gornall, A.G., C.J. Bardawill and M.M. David, 1949. Denaturation of serum proteins by means of the biuret reaction. J. Biol. Chem., 751-766.

Hossain, M.I., 1995. Studies on the post-mortem changes in mrigal (Cirrhina mrigala) M. Sc. Thesis. Department of Fisheries Technology. Bangladesh Agricultural University, Mymensingh.

Hossain, M.I., F.H. Shikha and A.Z.M.H.H. Shuva, 2019. Changes in muscle gel-forming ability, protein solubility and $\mathrm{pH}$ of three marine fish species of Bangladesh during ice storage. Bangladesh J. Fish., 31(1): 137-146.

Hossain, M.I., M. Kamal, M.N. Sakib, F.H. Shikha, M. Neazuddin and M.N. Islam, 2005. Influence of ice storage on the gel forming ability, myofibrillar protein solubility and $\mathrm{Ca} 2+-$ ATPase activity of Queen fish (Chorinemus lysan). J. Biol. Sci., 5(4): 519-524.

Ishiorishi, M., K. Samejima and T. Yasui, 1982. Further studies on the role of head and tail regions of myosin molecule in heat induced gelation. J. Food Sci., 47: 114-120.

Iwamoto, M. and H. Yamanaka, 1986. Remarkable differences in rigor-mortis between wild and cultured specimens of the red sea bream. Nipp. Suis. Gukk., 52: 275-279.

Iwamoto, M., H.M. Ioka, M. Saito and H. Yamanaka, 1985. Relation between rigor-mortis of sea bream and storage temperature. Nipp. Suis. Gukk., 51: 443-446.

Iwamoto, M., H. Yamanaka, S. Watabe and K. Hashimoto, 1987. Effect of storage temperature on rigor mortis and ATP degradation in plaice muscle, J. Food Sci., 52: 1514-1517.

Kurokawa, T., 1982. Quality of commercial frozen surimi of sardine. Nipp. Shok. Kogy. Gokk., 29: 48-54.

Mehta, N.K., K. Elavarasan, A.M. Reddy and B.A. Shamasundar, 2014. Effect of ice storage on the functional properties of proteins from a few species of fresh water fish (Indian major carps) with special emphasis on gel forming ability. J Food Sci Technol., 51(4): 655-663.

Niwa, E., A.A. Nowsad. and S. Kanoh, 1991. Changes in the visco-elastic properties of salted fish flesh sol during its low temperature setting. Nipp. Suis. Gakk., 57 (12): 2333-2336. 
CHANGES IN GEL FORMING ABILITY AND PROTEIN SOLUBILITY OF PANGASIUS AT DIFFERENT RIGOR

Nowsad, A.A., A.H. Khan, M. Kamal, S. Kanoh and E. Niwa, 1999. The effects of heating and washing on the gelling properties of tropical major carp muscle. J. Aquat. Food Prod. Technol., 8(2): 5-23.

Penny, I.F., 1967. The influence of $\mathrm{pH}$ and temperature on the properties of myosin. Biochem. J., 104: 609-615.

Perry, S.V. and T.C. Grey, 1956. A study on the effect of substrate concentration and certain relaxing factors on the magnesium activated myofibrillar adenosine triphosphate. Biochem. J., 64: 184-192.

Poon, K.H., P.Y. Lim, M.C. Ng and P.C. Ng, 1981. The suitable of leached meat of small demersal fish for making fish, jelly products. Singapore, Pri. Ind., 9(1): 28-37.

Repponed, K.D., J.K. Bubbitt, S. Berntesen and M. Tsuruta, 1995. Gel properties of surimi from Pacific herring. J. Food Sci., 61: 790-785.

Roussel, H. and J.C. Cheftel, 1988. Characteristics of surimi and kamaboko from sardine. Int. J. Food Sci. Tech., 23: 607-623.

Seki, N., M. Ikeda and N. Narita, 1979. Changes in ATPase activities of carp myofibrillar proteins during ice storage. Nipp. Suis. Gakk., 45: 791-799.

Shimizu, Y. and A. Kaguri, 1986. Influence of death condition and freshness on the gel forming property of fish. Nipp.Susi. Gakk., 52: 1837-1841.

Shimizu, Y., R. Machida and S. Takenami, 1981. Species variation in the gel-forming characteristics of fish meat paste. Bull. Japan. Soc. Sci. Fish., 47: 95-104.

Varghesecorresponding, T. and S. Mathew, 2017. Assessment of the textural variation of iced stored Anabas testudineus (Bloch, 1792) muscle tissue with emphasis on their collagen and myofibrillar protein content. J. Food Sci. Technol., 54(8): 2512-2518.

Watabe, S., M. Kamal and K. Hshimoto, 1989. Changes in $\mathrm{Ca}^{++}$-ATase activity of sardine ordinary and dark muscle myofibrils during storage at various $\mathrm{pH}$ values. Nipp. Suis. Gukk., 55: 703-707.

(Manuscript received 7 November 2020) 